University of South Florida

DIGITAL COMMONS

Digital Commons @ University of

@ UNIVERSITY OF SOUTH FLORIDA

South Florida

$2-1-2003$

\title{
A Loop Current Intrusion Case Study on the West Florida Shelf
}

Ruoying He

University of South Florida

Robert H. Weisberg

University of South Florida, weisberg@marine.usf.edu

Follow this and additional works at: https://digitalcommons.usf.edu/msc_facpub

Part of the Marine Biology Commons

\section{Scholar Commons Citation}

He, Ruoying and Weisberg, Robert H., "A Loop Current Intrusion Case Study on the West Florida Shelf" (2003). Marine Science Faculty Publications. 151.

https://digitalcommons.usf.edu/msc_facpub/151

This Article is brought to you for free and open access by the College of Marine Science at Digital Commons @ University of South Florida. It has been accepted for inclusion in Marine Science Faculty Publications by an authorized administrator of Digital Commons @ University of South Florida. For more information, please contact digitalcommons@usf.edu. 


\title{
A Loop Current Intrusion Case Study on the West Florida Shelf*
}

\author{
RuOYing HE AND RoBERT H. WEISBERG \\ College of Marine Science, University of South Florida, St. Petersburg, Florida
}

12 December 2001 and 19 August 2002

\begin{abstract}
The Gulf of Mexico Loop Current intruded upon the West Florida continental shelf in June 2000. In situ currents and hydrography along with satellite temperature and altimetry measurements are used to describe this event and its effects on the shelf. A strong southward current is observed to flow along the shelf slope seaward of the intruded water boundary. This current transported cold, nutrient-rich water from the north, thereby producing anomalous hydrographic features near the shelf break (80-m isobath). An array of moored velocity profilers reveals that the currents landward of the intruded water are independent of the Loop Current and primarily driven by local winds. A series of idealized numerical model simulations inclusive of forcing by both the Loop Current and local winds confirm the observational findings that the shelfbreak currents are largely Loop Current controlled while the shelf currents are largely controlled by the local winds.
\end{abstract}

\section{Introduction}

The West Florida continental shelf (WFS) is broad and gently sloping with its $100-\mathrm{m}$ isobath situated some 150-200 km offshore. The WFS circulation, driven by tides, winds, and buoyancy fluxes, is also influenced by the Gulf of Mexico Loop Current (LC) that enters through the Yucatan Strait and exits as the Gulf Stream though the Straits of Florida. Tidal currents are relatively weak (e.g., Koblinsky 1981; He and Weisberg 2002a), and subtidal sea level and current variations are correlated with synoptic-scale wind variations (e.g., Niiler 1976; Mitchum and Sturges 1982; Cragg et al. 1983; Marmorino 1983; Weisberg et al. 2001). What remains unclear is how deep-ocean and shelf waters interact and how such interactions influence the shelf circulation and water properties.

With the important issue of LC effects on the WFS unresolved, the present paper provides a case study of an LC impact event for which in situ currents and hydrographic data exist across the entire shelf. Analyses of satellite sea surface temperature (SST) and sea surface height (SSH) information together with the in situ data indicate that the inner-shelf and shelfbreak regions act independent of one another as the LC impacts the shelf break. To reconcile the observed features, we then

* Ecology of Harmful Algal Blooms Contribution Number 57.

Corresponding author address: Dr. Ruoying He, College of Marine Sciences, University of South Florida, St. Petersburg, FL 33701. E-mail: ruoying@marine.usf.edu perform numerical model experiments [using the primitive equation, Princeton Ocean Model (POM) of Blumberg and Mellor (1987)] under idealized forcing by the $\mathrm{LC}$ and by local winds. Section 2 describes the relevant data of June 2000. Section 3 presents the idealized LC model and the experimental results, with and without wind forcing. Section 4 then summarizes and discusses the implications of our findings.

\section{Data}

Intrusions of the LC into the eastern Gulf of Mexico and onto the WFS are the topic of several papers, but each with limited datasets (e.g., Leipper 1970; Niiler 1976; Molinari et al. 1977; Behringer et al. 1977; Huh et al. 1981; Paluszkiewicz et al. 1983). As part of an Ecology of Harmful Algal Blooms (ECOHAB) regional field study we encountered an LC intrusion onto the central portion of the WFS $\left(26^{\circ}-28^{\circ} \mathrm{N}\right)$ in June 2000. This section describes the intrusion using shipboard hydrographic data, satellite remotely sensed SST and SSH products, and water column velocity data from moored acoustic Doppler current profilers (ADCPs).

\section{a. Hydrographic data}

The multidisciplinary Florida ECOHAB project conducted monthly hydrographic surveys on the central WFS over the approximate three-year period beginning in summer 1998. The cruise track included transects offshore of Sarasota, Florida, that extended across the shelf between the $10-\mathrm{m}$ and the $200-\mathrm{m}$ isobaths (Fig. 

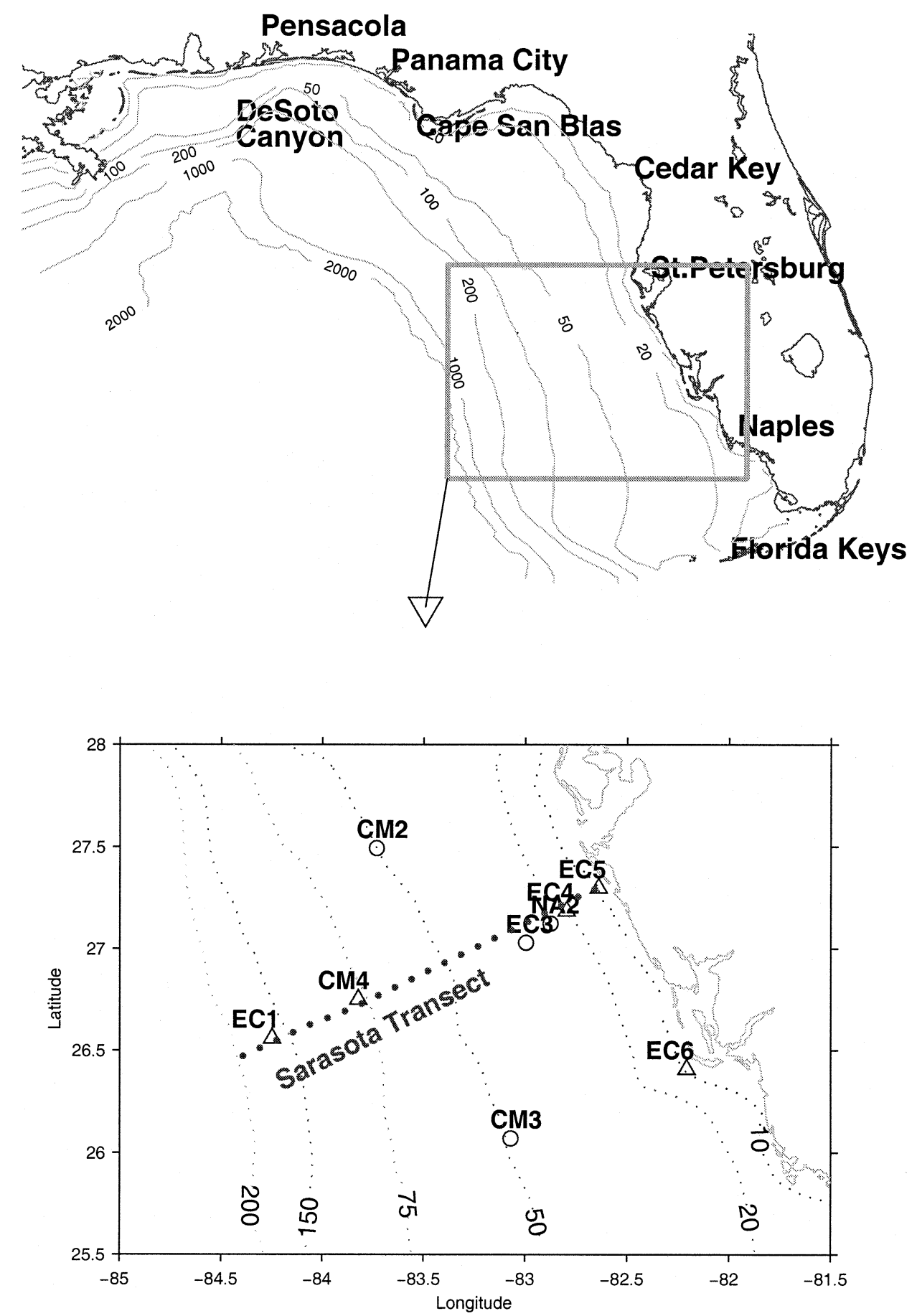

FIG. 1. West Florida shelf geometry, locations of the hydrographic casts (denoted by dots), and moored ADCP measurements (triangles denote upward-looking and circles denote downward-looking ADCPs).

1). CTD casts along with biological and chemical measurements were taken every $5 \mathrm{~nm}$. Two such hydrographic cruises were performed in June 2000 (6-8 and 28-30 June), with a total 57 CTD casts for each cruise: 22 along the Sarasota transect. Figure 2 shows the across-shelf structures of the temperature, salinity, density, and chlorophyll fluorescence fields measured along the Sarasota transect on 6 and 28 June. Steeply sloping isotherms are observed seaward of the shelf break suggestive of a strong southward baroclinic current. Straddling the shelf break at the bottom is a mass of relatively cold and fresh water upwelled from deeper depths. Water of this temperature and salinity occupies the monotonic, positive slope portion of the $T-S$ curve found 

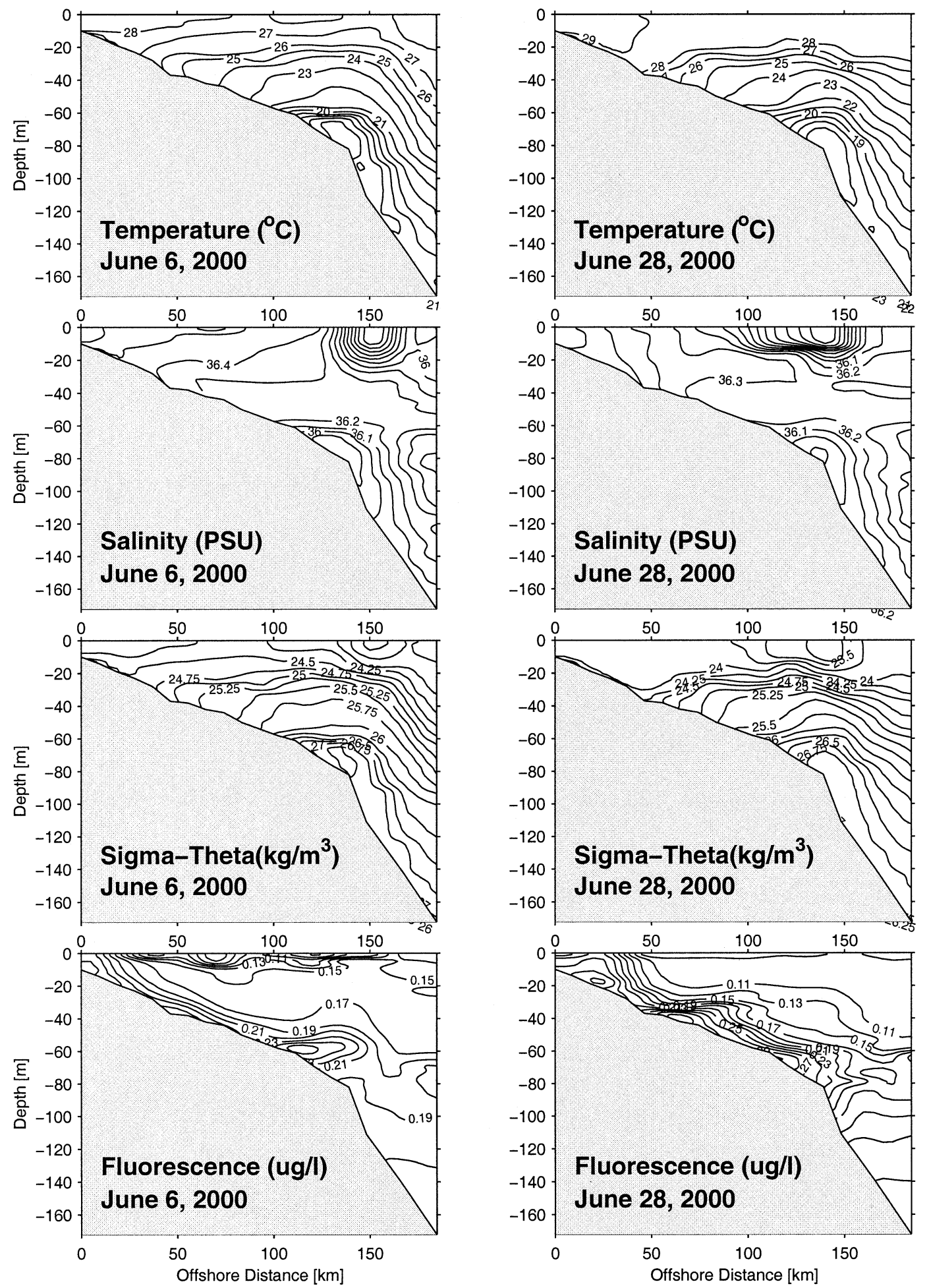

FIG. 2. Across-shelf (Sarasota transect) distributions of temperature, salinity, density, and chlorophyll fluorescence sampled on (left) 6 and (right) 28 Jun. 
between Antarctic Intermediate Water of Southern and 18-Degree Water of Northern Hemisphere origins (e.g., Schmitz and Richardson 1991), and is characteristic of middepth waters found within the LC. While a consequence of upwelling, this water did not upwell locally, as evidenced in the lack of connectivity along the Sarasota transect between water properties at the shelf break and those farther offshore. We surmise that upwelling occurred farther north and that the upwelled water was advected by the shelfbreak currents. How this may have occurred will be discussed in section 4 . The appearance of such anomalously cold water at the shelf break in June 2000 is also unique to the monthly ECOHAB cruise data. All other Sarasota hydrographic sections from June 1998 to September 2001 show that waters of $16^{\circ} \mathrm{C}$ or colder were below $170 \mathrm{~m}$, whereas here it is as shallow as $70 \mathrm{~m}$.

Chlorophyll fluorescence is also interesting. Qualitatively, we see high fluorescence originating at the shelf break in the vicinity of the upwelled water and extending inshore along the bottom. Chlorophyll fluorescence requires two ingredients: nutrients and light. The upwelled water provides the nutrients, and the shallow depths provide for the light. Nutrient concentrations may also be elevated near shore due to land drainage through the Tampa Bay and Charlotte Harbor estuaries. These two sources of nutrients (shelf break and near shore), both with available light, are connected through the bottom Ekman layer. Thus, and especially under stratified conditions (e.g., Weisberg et al. 2001), the bottom Ekman layer provides an effective across-shelf conduit for the delivery of biologically important materials. As will be shown later, the inner-shelf circulation in June 2000 was primarily of a wind-induced downwelling type. This is reflected in the changes of the temperature, density, and fluorescence isolines between the 6 and 28 June transects, attesting to the bottom Ekman layer playing an essential role in the WFS biological productivity.

Using the thermal wind relationship and assuming a reference level of zero baroclinic geostrophic current at the bottom, we compute the alongshelf velocity distributions for the 6 and 28 June transects (Fig. 3). Corresponding to the largest across-shelf density gradients, the strongest southward flows are observed near the shelf break with magnitudes of about $0.70 \mathrm{~m} \mathrm{~s}^{-1}$ on 6 June and $0.45 \mathrm{~m} \mathrm{~s}^{-1}$ on 28 June. As anticipated from the Taylor-Proudman theorem (e.g., Brink 1998), these LC-related southward currents diminish in magnitude to zero within $10-20 \mathrm{~km}$ of the shelf break, and consistent with the baroclinic Rossby radius of deformation $(\mathrm{NH} / f)$ calculated at the current core, the scale width of these primarily baroclinic currents are about 30-35 $\mathrm{km}$, as observed. As a result, the geostrophically inferred currents on the shelf are comparatively weak, with speeds generally less than $0.05 \mathrm{~m} \mathrm{~s}^{-1}$.

\section{b. Satellite data}

Complementing the shipboard hydrographic measurements are satellite-derived images of SST (by

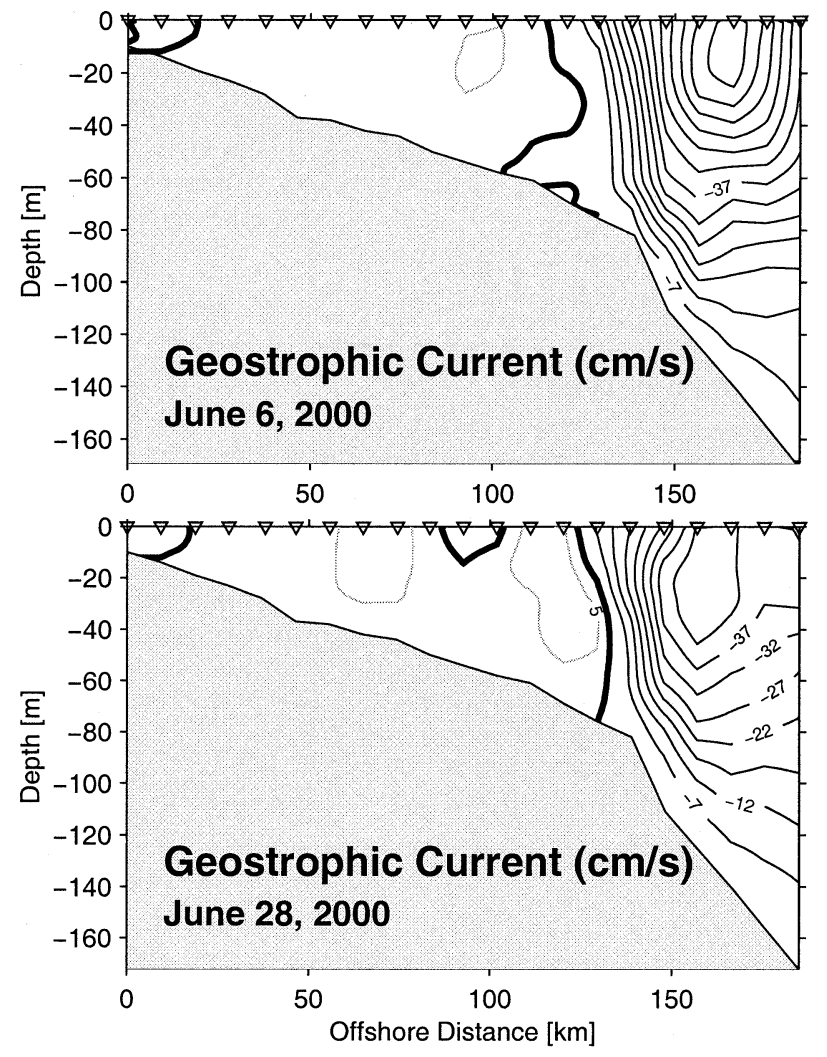

Fig. 3. Calculated across-shelf (Sarasota transect) geostrophic currents on (top) 6 and (bottom) 28 Jun. The contour interval is $5 \mathrm{~cm}$ $\mathrm{s}^{-1}$, and southward currents are denoted by solid lines.

AVHRR) and SSH (by TOPEX/ERS-2 altimetry). These provide the larger-scale picture of the environmental conditions sampled along the ship track. Our analysis period, chosen to bracket the ship surveys, is 1 June6 July. The SST images were obtained from the Applied Physics Laboratory, the Johns Hopkins University, and the SSH images were obtained from the Colorado Center for Astrodynamics Research, University of Colorado. These are shown in Figs. 4, 5, and 6. Each panel includes the 75-m and 200-m isobaths to indicate the position of the $\mathrm{LC}$ relative to the WFS.

Figure 4 is the 6 June SST image. A well-defined frontal feature is observed south of $28^{\circ} \mathrm{N}$ as a band of relatively cold water that loops around and strikes the WFS between the 200- and 75-m isobaths. As evidenced in the shipboard hydrography, this is where the thermocline intersects the surface at the outer edge of the LC.

How these features evolve over the case study period 1 June to 6 July is shown for SST and SSH in Figs. 5 and 6 , respectively. The cold, outer edge of the LC penetrating the shelf to between the 200- and 75-m isobaths is clearly evident as an anticyclonically wrapping filament from 1-8 June, after which the feature becomes more amorphous as SST homogenizes with summertime surface heating. The ECOHAB hydrography shows this 

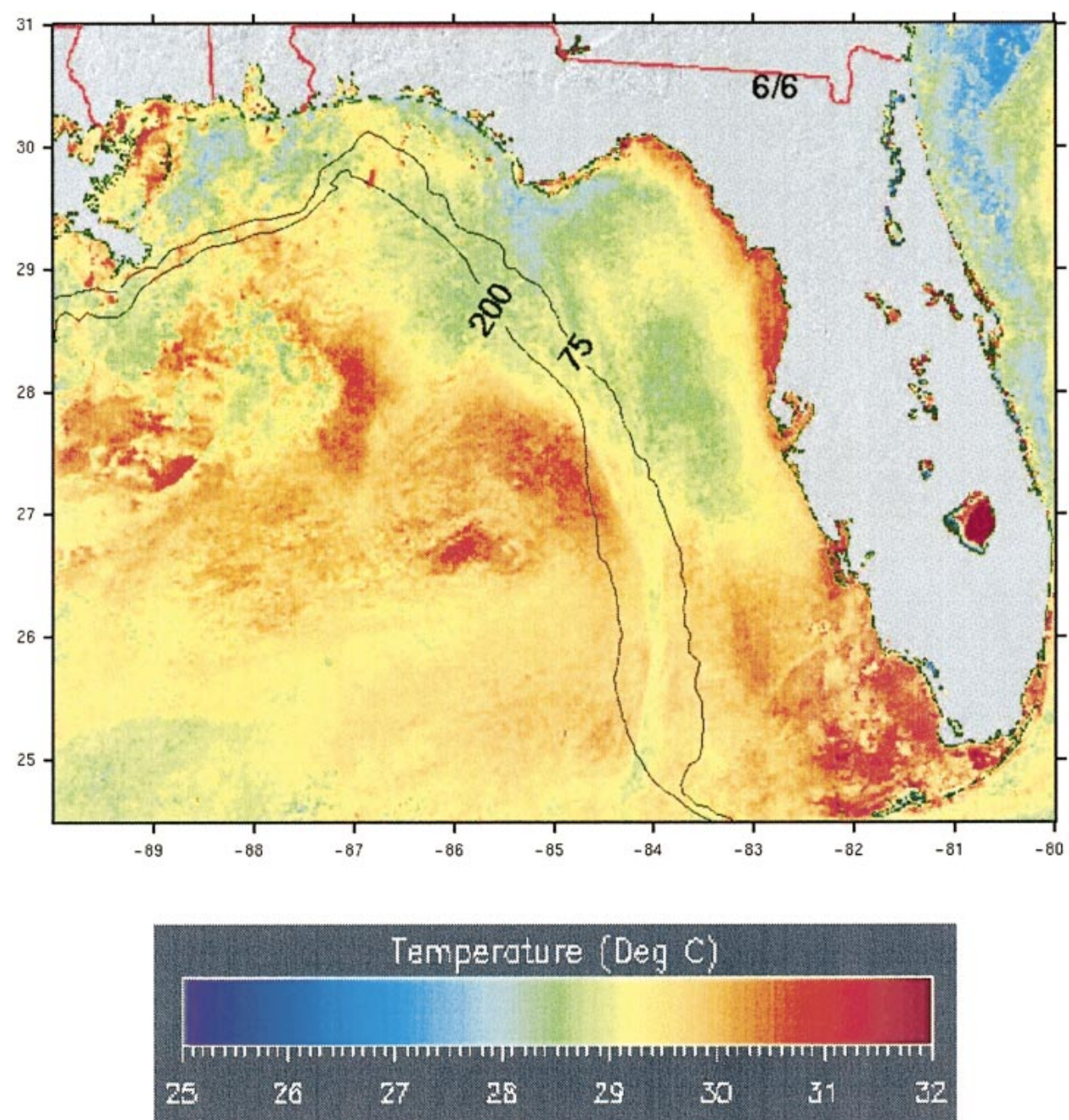

FIG. 4. AVHRR SST on 6 Jun 2000 obtained (with permission) from the Applied Physics Laboratory at the Johns Hopkins University. The 75- and 200-m isobath contours are overlaid to show the LC front penetration onto the WFS.

filament to be located at the shelf break (approximately at the $80-\mathrm{m}$ isobath on this transect) on 6 June (Fig. 2), where the $28^{\circ} \mathrm{C}$ isotherm broaches the surface. The SSH gradient features support these SST descriptions. A gradient in SSH is evident on the shelf break through around 8 June, after which the leading edge of the LC retreats offshore and to the south. On around 22 June the leading edge of the LC again sidles toward the northeast and impacts the shelf break. By early July there is evidence of an across-shelf directed component to the LC flow at the continental slope, looping around anticyclonically to become an alongshelf flow in the vicinity of the shelf break.

\section{c. Current data}

An array of ADCP moorings (Fig. 1) provides in situ current measurements for the case study period. The array spanned the entire shelf with moorings at the 150-
(EC1), 75- (CM4), 50- (CM2), 30- (EC3), 25- (NA2), 20- (EC4), and 10-m (EC5 and EC6) isobaths. The outermost moorings (150- and 75-m isobaths) were deployed on 25 June so these coincide only with the later part of the case study. After low-pass filtering to remove tidal and inertial oscillations and other fluctuations at timescales shorter than $36 \mathrm{~h}$, daily velocity vector averages are shown for the near-surface and near-bottom bins in Figs. 7 and 8, respectively. The location of these bins varies with the instrument depth and mooring type (buoyed by surface or subsurface floatation or mounted at the bottom), and at each location we show velocity data from the (uncontaminated) bins closest to either the surface or the bottom. Also shown are coastal wind velocity vectors from Venice, Florida, similarly lowpass filtered and then daily averaged. Note the different scales used for each of the vector presentations. In particular the bold vector used to distinguish the $150-\mathrm{m}$ isobath currents from the others is largely reduced in 


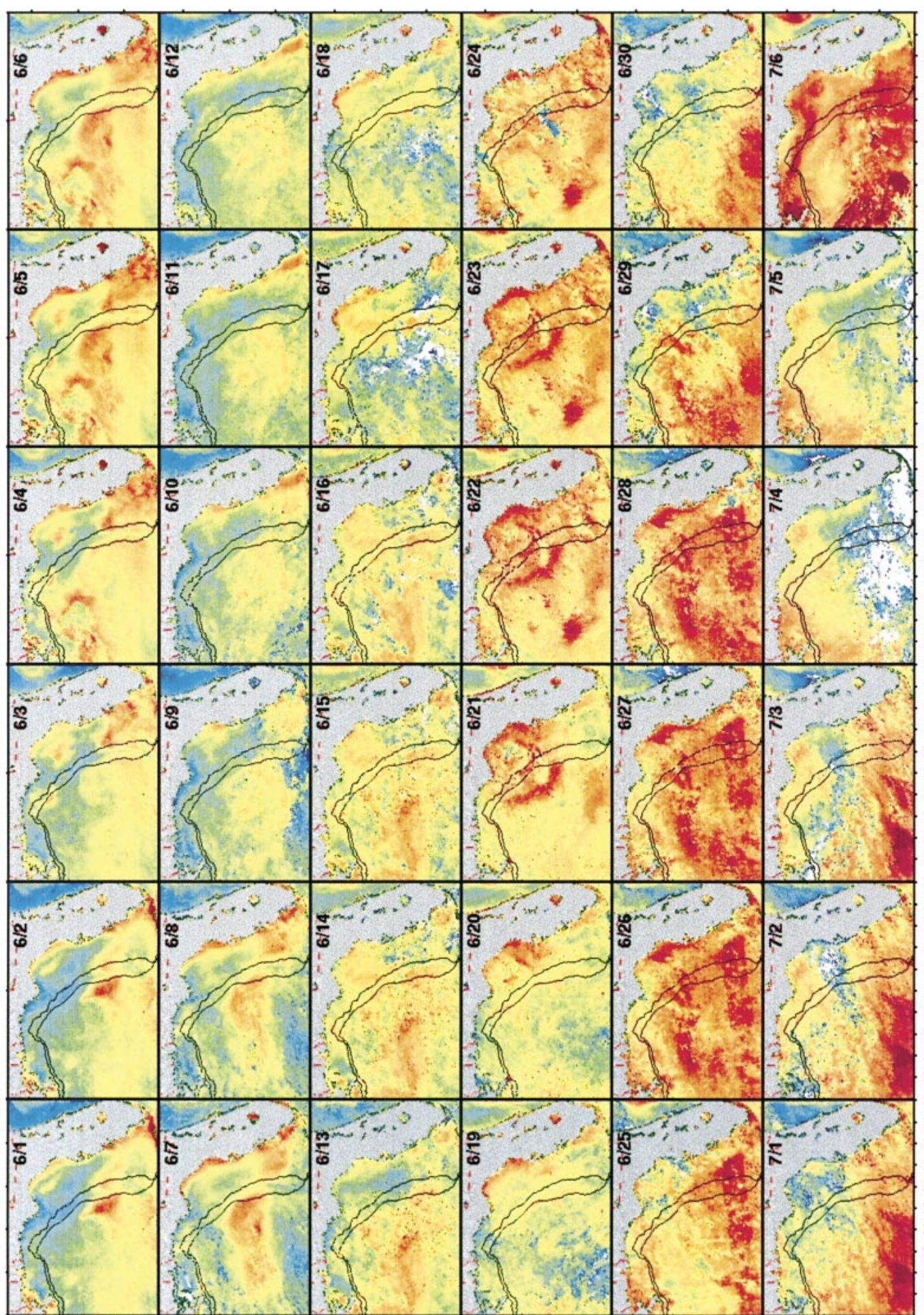

-

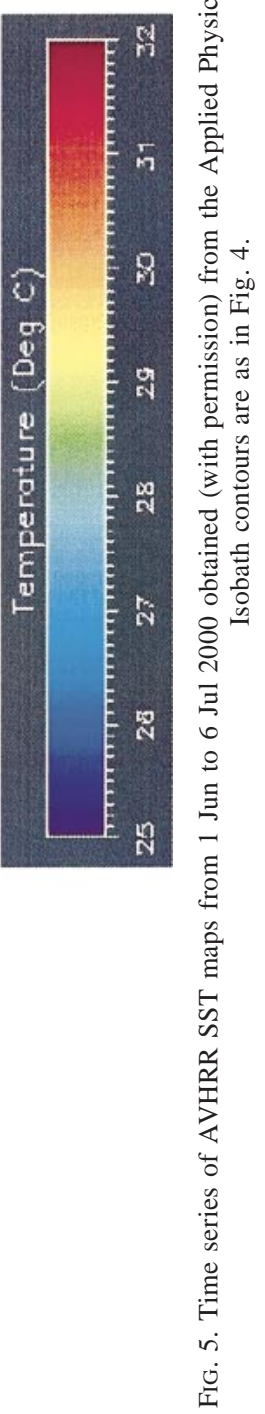



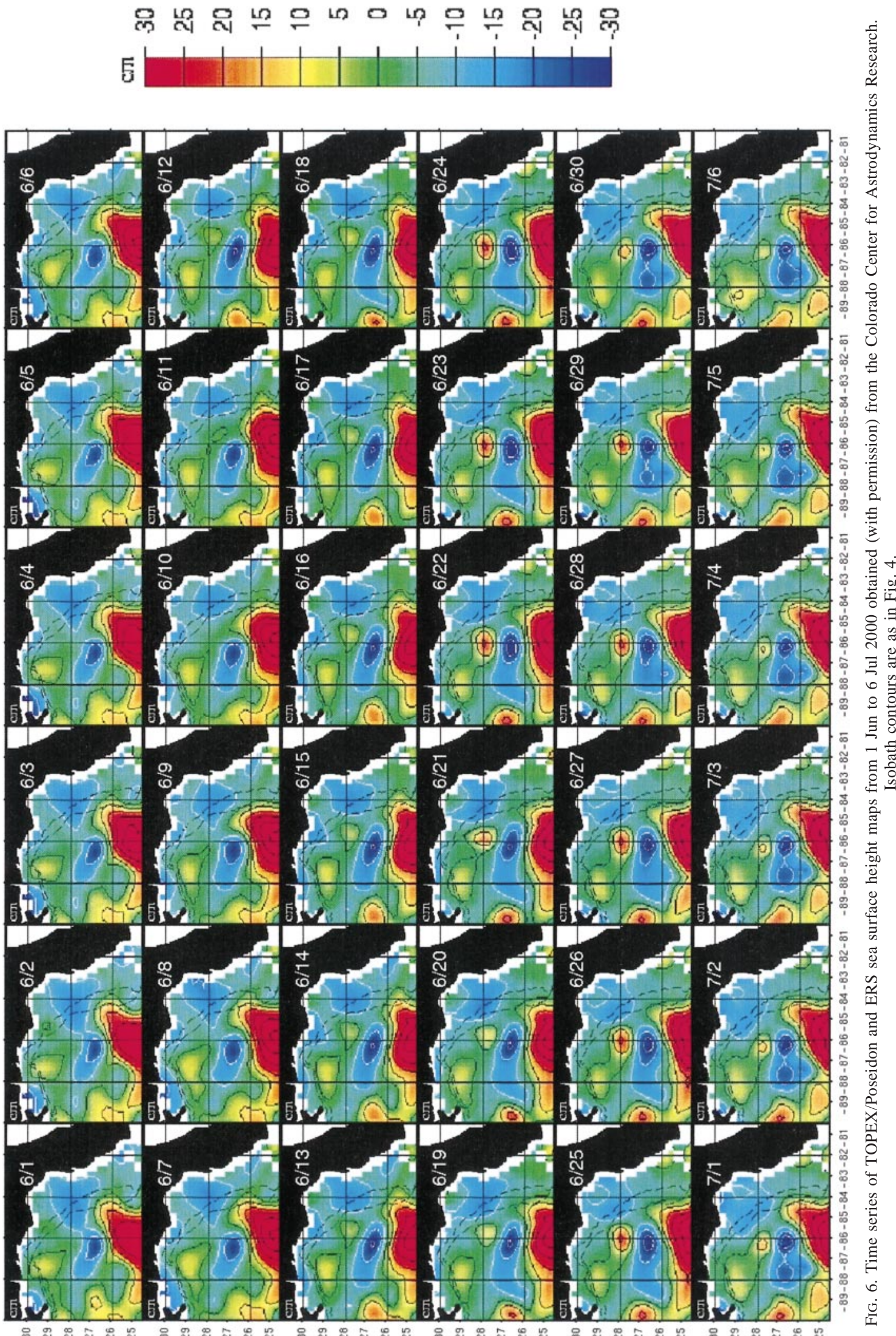


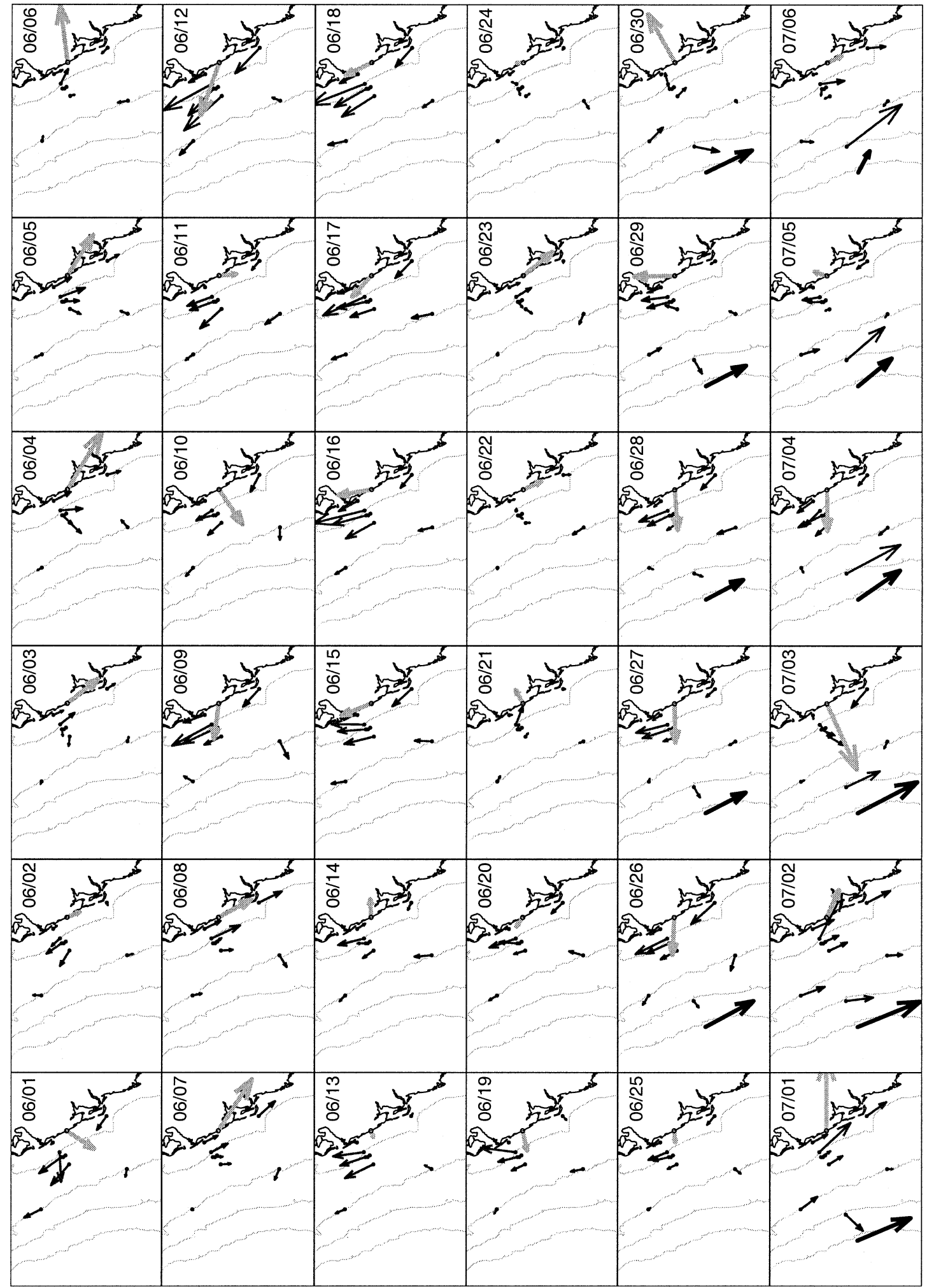




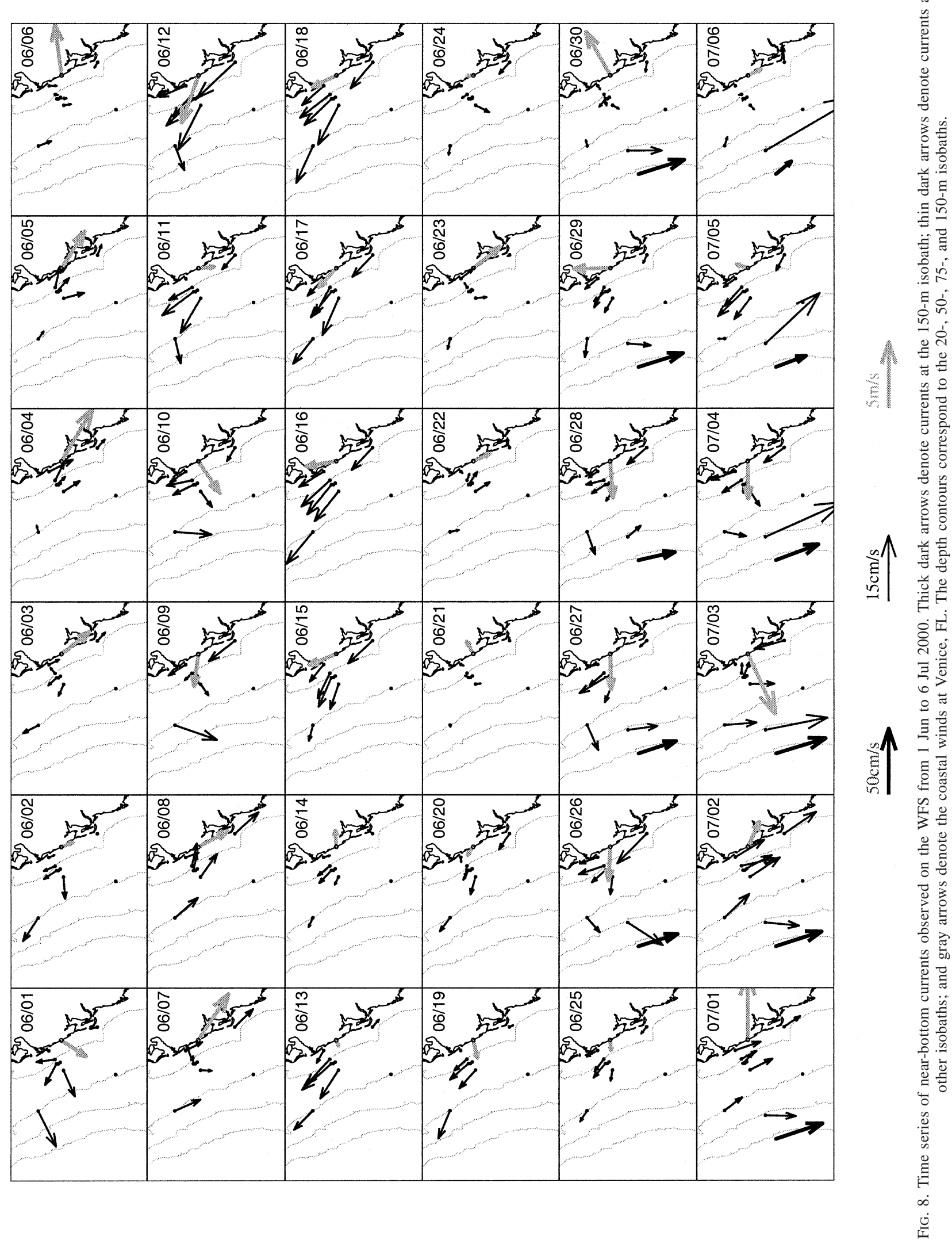



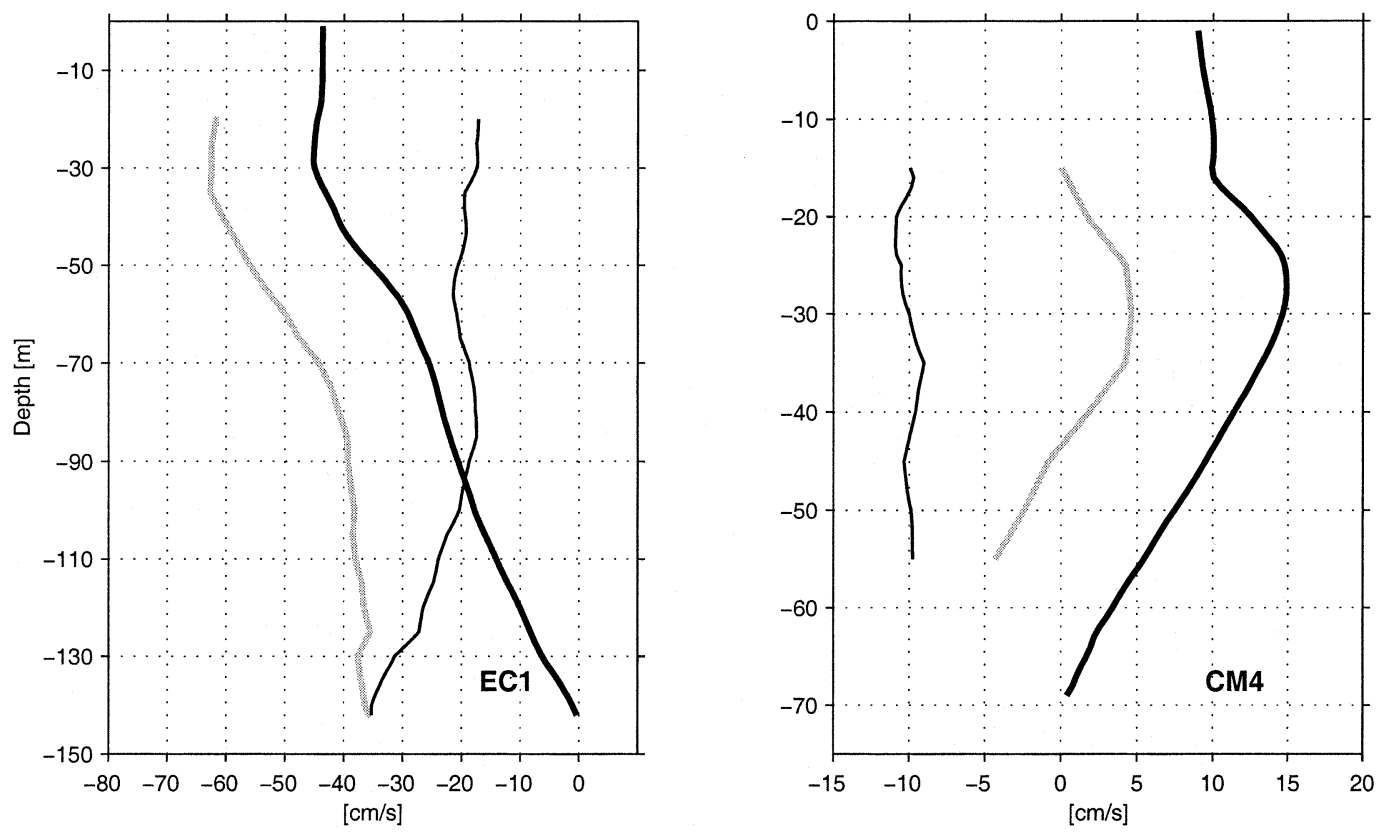

FIG. 9. The 28 Jun depth profiles of the ADCP observed currents (thick light lines), the thermal-wind-calculated baroclinic geostrophic currents (thick dark lines), and their difference (thin dark lines) at the (left) 150- and (right) $75-\mathrm{m}$ isobaths.

dimension since these currents are much stronger. Thus, after 4 July, when the vectors at the 75-m isobath appear larger than those at the $150-\mathrm{m}$ isobath, the velocity disparity is actually about 3 times as small as it looks. Similarly, the near-bottom currents are accentuated by a factor of 2 relative to the near-surface currents since the near-bottom currents tend to be relatively smaller. Markedly different behaviors are seen between the currents observed on the inner shelf versus those observed near the shelf break. Over the inner shelf [e.g., see Lentz (1994) and Weisberg et al. (2001) for related but different definitions], taken here to be roughly inshore of the 50-m isobath, the current variations are determined primarily by the local winds. This is not the case at the 150- and 75- $\mathrm{m}$ isobaths where the LC intrusion is most influential. On 26 June we see a substantial alongshelfdirected current at the $150-\mathrm{m}$ isobath in isolation from any of the locations farther inshore, including the 75$\mathrm{m}$ isobath. Currents at the $75-\mathrm{m}$ isobath begin to flow alongshelf with those at the $150-\mathrm{m}$ isobath around 3 July, and they peak in magnitude on 7 July, after which the extended record shows that they diminish again. The largest near-surface and near-bottom currents during this time interval occur on 3 July at the $150-\mathrm{m}$ isobath at about 1.0 and $0.4 \mathrm{~m} \mathrm{~s}^{-1}$, respectively. On 7 July the near-surface and near-bottom currents at the $75-\mathrm{m}$ isobath are about 0.3 and $0.25 \mathrm{~m} \mathrm{~s}^{-1}$, respectively. Current measurements at both of these locations extend through September 2001. Typical speeds are about 0.1-0.2 m $\mathrm{s}^{-1}$. Thus, the strong current event reported here is unique for this 15-month-long record. From these observations and those previously reported by Meyers et al. (2001), it appears that LC impacts on the central portion of the WFS are infrequent and when they occur they affect the currents near the shelf break, leaving the currents over the inner shelf largely driven by local forcing (winds and buoyancy fluxes).

Compatible with the geostrophic assumption made for Fig. 3 we may also analyze the ADCP velocity profile to estimate the barotropic component to the total flow. Thus, we set the Coriolis force equal to the sum of the barotropic and the baroclinic contributions to the pressure gradient force,

$$
\begin{aligned}
v & =v_{\text {barotropic }}+v_{\text {baroclinic }} \\
& =v_{\text {barotropic }}+\frac{g}{f \rho_{0}} \frac{\partial}{\partial x} \int_{-H}^{0} \rho(z) d z
\end{aligned}
$$

with the vertical shear of the observed alongshelf current equaling the vertical shear of the baroclinic current calculated by thermal wind. Figure 9 compares the ADCPobserved and the thermal-wind-calculated alongshelf velocity component profiles for both the 75- and 150$\mathrm{m}$ isobaths on 28 June. The vertical shears agree well over the ranges for which data are available. The implied barotropic portions of the flows at the 150- and 75-m isobaths are about 0.2 and $0.1 \mathrm{~m} \mathrm{~s}^{-1}$, respectively. The barotropic portions of the flows at both locations are directed southward, whereas the baroclinic portions are reversed (southward at the $150-\mathrm{m}$ isobath and northward at 75-m isobath). So while the barotropic portion of the shelf response to this LC intrusion extends across the shelf break, a node is crossed for the baroclinic portion due to the doming of the isopycnals at the shelf break. 


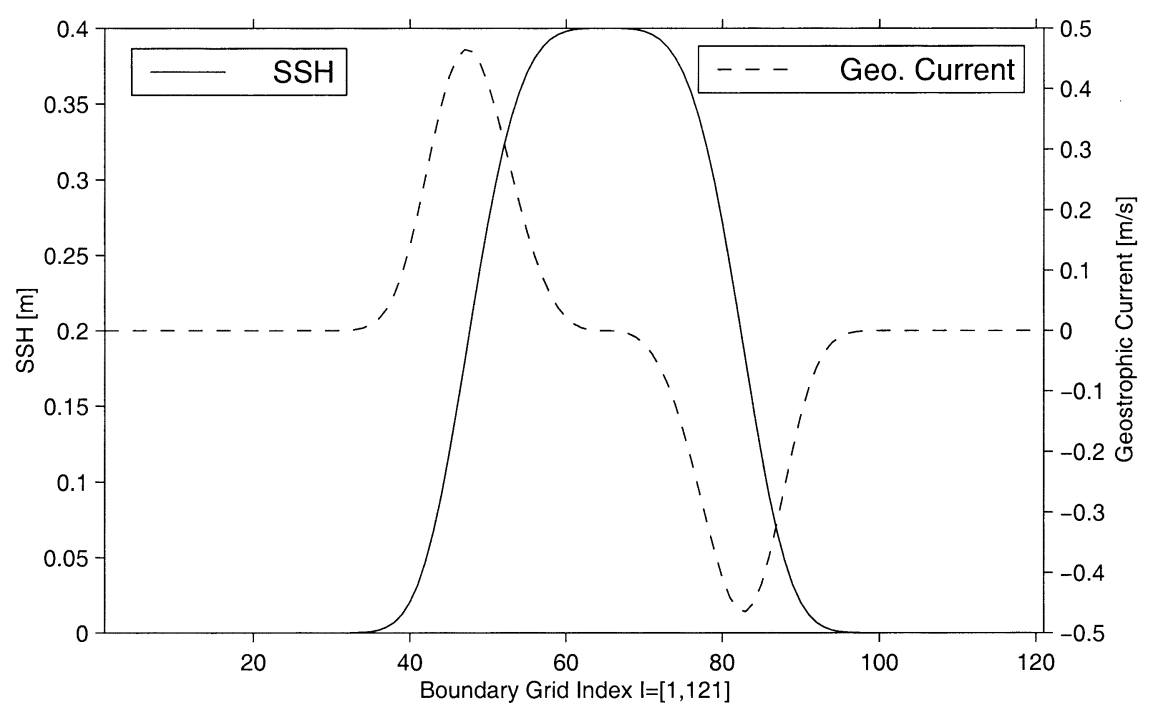

FIG. 10. Sea surface height (solid line) and associated geostrophic current (dashed line) distributions along the WFS shelf circulation model open boundary.

This counteracting affect of the barotropic and baroclinic responses further limits the penetration of the LC intrusion onto the shelf. If we further assume a landward exponential decay (Chapman and Brink 1987) for the barotropic pressure gradient (or geostrophic current), this implies a reduction of the LC-induced barotropic current to $0.05 \mathrm{~m} \mathrm{~s}^{-1}$ by the $50-\mathrm{m}$ isobath, the magnitude of which is easily exceeded by the local wind-driven circulation. Thus, neither the baroclinic, nor the barotropic parts of the LC-induced circulation should be major factors on the inner shelf, consistent with Figs. 7 and 8.

\section{Numerical simulations}

The observations suggest that the inner-shelf and shelfbreak regions act independent of one another as the LC impacts the region of the shelf break. The LC controls the flow field in the vicinity of the shelf break, whereas local forcing controls the flow field over the inner shelf. We attempt to reconcile these observations by performing numerical model experiments under realistic geometry, but with idealized forcing. The model is a regional adaptation of the primitive equation, POM (Blumberg and Mellor 1987), the details of which are given in He and Weisberg (2002b). Our WFS adaptation extends from west of the Mississippi River in the northwest to the Florida Keys in the southeast with a single open boundary arching between these end points. We explore the role of the LC on the WFS by controlling the flows into and out of the open boundary while allowing the model LC to freely evolve within the model domain. Three types of experiments are performed, all with constant density to emphasize the barotropic response since previous studies (e.g., Chapman and Brink 1987) show that it penetrates farther inshore than the baroclinic response. The three experiments are 1) forcing by the LC only, 2) forcing by the LC plus upwellingfavorable winds, and 3) forcing by the LC plus downwelling-favorable winds.

We generate an LC by diagnostically imposing a sea level distribution along the open boundary:

$$
\eta=A_{0} e^{\left[-\left(x-x_{0}\right)^{4} / 2\right]},
$$

where $A_{0}$ is the amplitude of the sea level perturbation, $x$ is grid index along the open boundary, and $x_{0}$ is the grid index corresponding to the location of maximum sea level. Based on a geostrophic balance, the openboundary sea level distribution corresponds to regions of inflow in the north and outflow in the south. From the satellite altimetry analysis we set $A_{0}=0.4 \mathrm{~m}$, which corresponds to a geostrophic current magnitude of about $0.5 \mathrm{~m} \mathrm{~s}^{-1}$. Such current is a little smaller than observed at the shelf break but considerably larger than the barotropic portion in Fig. 9. These open-boundary sea level and geostrophic current distributions are given in Fig. 10. When wind stress is added, we use a uniform value of $0.1 \mathrm{~N} \mathrm{~m}^{-2}$ directed alongshore (with respect to the west Florida coastline) either to the southeast (upwelling) or to the northwest (downwelling). Each experiment consists of a 25-day model run in which a quasisteady state is reached within about 5 days.

Model results in the form of depth-averaged current fields are given in Fig. 11. The thick line along the open boundary corresponds to the region of sea level control, and the resulting model-determined LC inflows and outflows are clearly depicted. Figure 11a is with the LC only. Penetration of the LC into the model domain is greatly inhibited by the sloping topography. Currents intrude onto the shelf up to about the $200-100-\mathrm{m}$ isobaths, after which the vectors are imperceptibly small. Because of the cyclonic propagation of topographically 

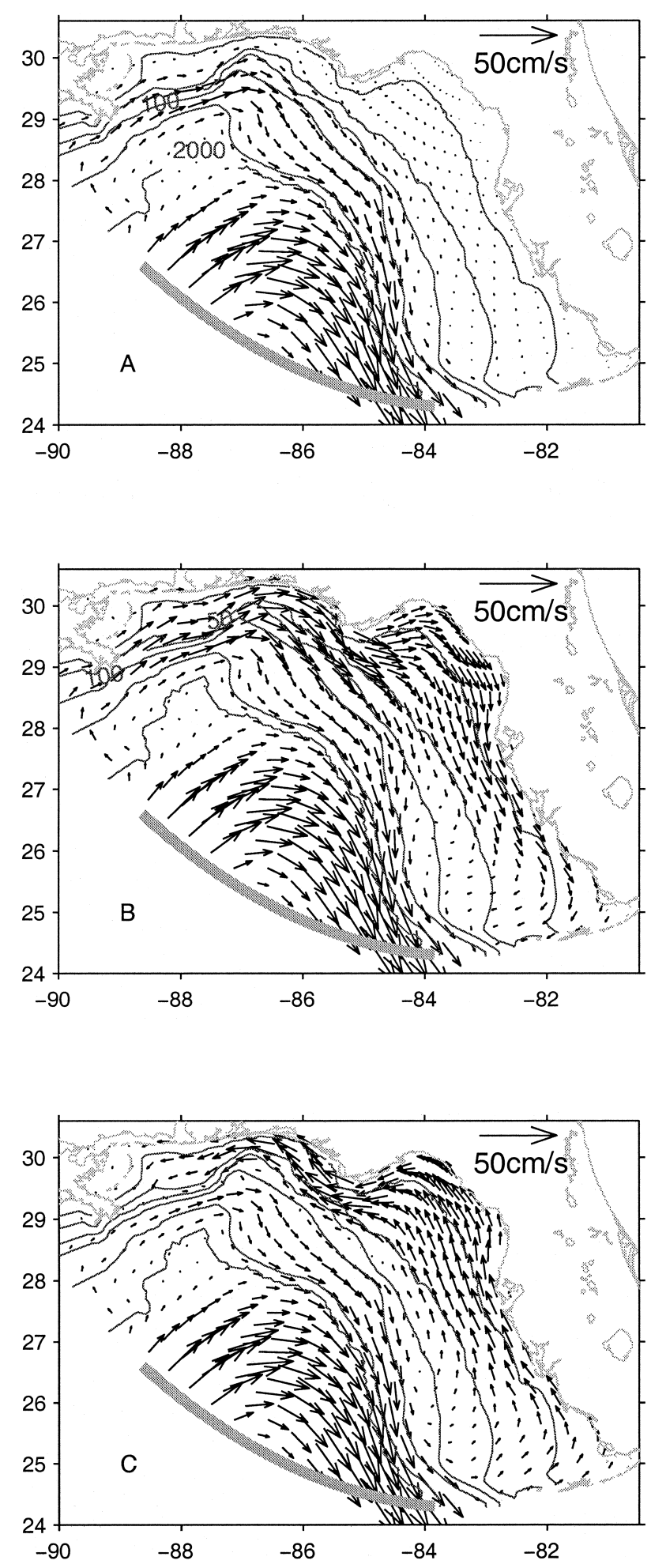

FIG. 11. Depth-averaged current maps from the idealized LC and wind-forced model experiments: (a) the LC-only case, (b) the case for LC plus upwelling-favorable $\left(0.1 \mathrm{~N} \mathrm{~m}^{-2}\right)$ winds, and (c) the case for LC plus downwelling-favorable $\left(0.1 \mathrm{~N} \mathrm{~m}^{-2}\right)$ winds. Thick lines along the open boundary indicate the sea surface height perturbation region. The depth contours correspond to the 20-, 50-, 100-, 200-, $1000-$, and 2000-m isobaths. trapped waves, the region along the shelf break to the north of the LC impact is also set into motion as a shelfbreak jet that extends to the northwest corner of the model domain. Where the shelf narrows at DeSoto Canyon in the north, this jet excites currents in shallower water consistent with the findings of Chapman and Brink (1987). Regardless of shelf width, however, wind forcing dominates the inner-shelf responses. Figures $11 \mathrm{~b}$ and 11c show the responses to the LC, plus either upwellingor downwelling-favorable winds, respectively. A more detailed analysis of the wind-driven responses alone under a constant density setting is given by Li and Weisberg $(1999 \mathrm{a}, \mathrm{b})$. The main point here is that given the mixture of the two forcing functions (LC and winds), the LC controls the shelf slope and break regions, whereas the winds control the inner-shelf region, as confirmed by our observations in Figs. 7 and 8. The model experiments, albeit simplified, are mutually supportive with the observations on the point that the inner-shelf and shelfbreak regions act nearly independently during such midpoint LC-shelf interaction events. They also provide observational/numerical model support for the general quasi-analytical work of Chapman and Brink (1987).

\section{Summary and discussion}

Using in situ currents and hydrographic data along with satellite SST and SSH analyses, we describe an LC intrusion event that occurred on the WFS in June 2000 and explore the relative roles of LC-induced and local wind-induced currents in accounting for the observations through idealized numerical model experiments. Consistent with the Taylor-Proudman theorem, the planetary vorticity constraint by the sloping bottom limits the barotropic portion of the LC penetration onto the shelf. Since the LC is largely baroclinic, the acrossshelf scale of the resulting current is compatible with the baroclinic Rossby radius of deformation evaluated near the shelf break. Penetration onto the shelf is further inhibited by the counteracting affects of the baroclinic and barotropic portions of the flow field. The barotropic portion, while of larger across-shelf scale, is counteracted by the baroclinic portion that reverses sign due to doming of isopycnals at the shelf break. Thus, the shelfbreak currents are largely LC-controlled, whereas the inner-shelf currents are largely controlled by the local winds.

Numerical experiments, using a regional adaptation of the POM with realistic topography and idealized barotropic, constant density forcing, supports the conclusion on the near independence between the LC-driven shelf break and the wind-driven inner shelf for this midpoint LC-shelf interaction. A barotropic LC impact on the shelf slope is confined seaward of the shelf break, setting up a shelf-slope current to the north (in the cyclonic direction of continental shelf wave propagation). Adding either upwelling- or downwelling-favorable 
winds demonstrates that the wind-driven responses greatly exceed the LC responses over the inner shelf.

Loop Current intrusions onto the WFS in reality have both barotropic and baroclinic parts. The isopycnals associated with the shelf-slope current to the north of the impact region therefore tilt upward toward the shelf causing relatively deep water to upwell at the shelf break. If the shelf break either shoals or the shelf narrows in the cyclonic direction, then water upwelled in the shelf-slope current may reach isobaths that are shallower than those that can be attained locally where the LC impacts the shelf. The WFS geometry provides both of these factors. The shelf break at the impact region is about $80 \mathrm{~m}$ deep, whereas in DeSoto Canyon it is about $40 \mathrm{~m}$ deep. The shelf also narrows appreciably between Cape San Blas and DeSoto Canyon (Fig. 1). The addition of wind-driven upwelling over the narrower portions of the shelf can further facilitate upwelling onto the shelf. Note that for the period 3-8 June, at the beginning of this LC intrusion event, the winds were upwelling favorable. Thus, the ingredients (an LC-induced shelf-slope jet with currents of magnitude $0.4 \mathrm{~m} \mathrm{~s}^{-1}$, upstream topography changes, and upwelling-favorable wind forcing) existed to account for the observed deepwater properties being upwelled and transported from the north.

Acknowledgments. Our measurement and modeling efforts are both supported by the Office of Naval Research Grant N00014-98-1-0158 and by the National Oceanic and Atmospheric Administration Grant NA76RG0463. Special thanks are offered to the family of Elsie and William Knight for the research fellowship endowment that helps to support R. He. Our evolving program of study on the WFS also benefited from previous support under a cooperative agreement between the U.S. Geological Survey, Center for Coastal Geology and the USF College of Marine Science and by the Minerals Management Service Cooperative Agreement 14-35-0001-30787. We thank the Applied Physics Laboratory at the Johns Hopkins University and the Colorado Center for Astrodynamics Research for making their satellite AVHRR and TOPEX/ERS analyses available on line, respectively. G. Vargo and C. Heil kindly provided the ECOHAB hydrographic data. We note that W. Hemme and Y. Liu assisted J. Donovan in processing the ADCP data, which R. Cole collected at sea continuing his nearly unblemished record.

\section{REFERENCES}

Behringer, D. W., R. L. Molinari, and J. F. Festa, 1977: The variability of anticyclone current patterns in the Gulf of Mexico. J. Geophys. Res., 82, 5479-5488.

Blumberg, A. F., and G. L. Mellor, 1987: A description of a threedimensional coastal ocean circulation model. Three-Dimensional Coastal Ocean Models, N. Heaps, Ed., Vol. 4, Amer. Geophys. Union, 208-233.

Brink, K. H., 1998: Wind-driven currents over the continental shelf. The Sea, K. H. Brink and A. R. Robinson, Eds., The Global Coastal Ocean, Vol. 10, John Wiley and Sons, 151-167.

Chapman, D. C., and K. H. Brink, 1987: Shelf and slope circulation induced by fluctuating offshore forcing. J. Geophys. Res., 92, $11741-11759$.

Cragg, J., G. Mitchum, and W. Sturges, 1983: Wind-induced seasurface slopes on the west Florida shelf. J. Phys. Oceanogr., 13, 2201-2212.

He, R., and R. H. Weisberg, 2002a: Tides on the west Florida shelf. J. Phys. Oceanogr., 32, 3455-3473.

__ and _ _ 2002b: West Florida shelf circulation and temperature budget for the 1999 spring transition. Cont. Shelf Res., 22, 719748.

Huh, O., W. J. Wiseman, and L. Rouse, 1981: Intrusion of loop current onto the west Florida continental shelf. J. Geophys. Res., 86, 4186-4192.

Koblinsky, C. J., 1981: The M2 tide on the West Florida Shelf. DeepSea Res., 28A, 1517-1532.

Leipper, D. F., 1970: A sequence of current patterns in the Gulf of Mexico. J. Geophys. Res., 75, 637-657.

Lentz, S. J., 1994: Current dynamics over the northern California inner shelf. J. Phys. Oceanogr., 24, 2461-2478.

Li, Z., and R. H. Weisberg, 1999a: West Florida continental shelf response to upwelling favorable wind forcing, part I: Kinematic description. J. Geophys. Res., 104, 13 507-13 527.

$\ldots$, and — 1999b: West Florida continental shelf response to upwelling favorable wind forcing, part II: Dynamical analyses. J. Geophys. Res., 104, 23 427-23 442.

Marmorino, G. O., 1983: Wind-forced sea level variability along the West Florida shelf, winter, 1978. J. Phys. Oceanogr., 12, 389 405.

Meyers, S. D., E. M. Siegel, and R. H. Weisberg, 2001: Observation of currents on the West Florida shelf break. Geophys. Res. Lett., 28, 2037-2040.

Mitchum, G., and W. Sturges, 1982: Wind-driven currents on the West Florida shelf. J. Phys. Oceanogr., 12, 1210-1217.

Molinari, R. L., S. Baig, D. W. Behringer, G. A. Maul, and R. Legeckis, 1977: Winter intrusions of the loop current. Science, 198, 505-506.

Niiler, P. P., 1976: Observations of low-frequency currents on the West Florida continental shelf. Mem. Soc. Roy. Sci. Liege, 6, 331-358.

Paluszkiewicz, K., L. P. Atkinson, E. S. Posmentier, and C. R. McClain, 1983: Observations of a loop current frontal eddy intrusion onto the west Florida shelf. J. Geophys. Res., 88, 96399651.

Schmitz, W. J., Jr., and P. L. Richardson, 1991: On the source of the Florida Current. Deep-Sea Res., 38 (Suppl.), S389-S409.

Vukovitch, F. M., B. W. Crissman, M. Bushnell, and W. J. King, 1979: Some aspects of the oceanography of the Gulf of Mexico via satellite and in situ data. J. Geophys. Res., 84, 7749-7768.

Weisberg, R. H., Z. Li, and F. Muller-Karger, 2001: West Florida shelf response to local wind forcing, April 1998. J. Geophys. Res., 106 (C12), 31 239-31 262. 